\title{
FAKTOR KEUANGAN DAN FAKTOR NON KEUANGAN YANG MEMPENGARUHI KETEPATAN WAKTU PUBLIKASI LAPORAN KEUANGAN PERUSAHAAN SEKTOR PERTAMBANGAN YANG TERDAFTAR DI BURSA EFEK INDONESIA TAHUN 2015 - 2019
}

\author{
Yoladia Ibrahim ${ }^{1}$ \\ Dicky Arisudhana ${ }^{2}$
}

Program Studi Akuntansi, Fakultas Ekonomi dan Bisnis Universitas Budi Luhur ${ }^{1,2}$ Email: yoladiai@gmail.com ${ }^{1}$; dicky.arisudhana@budiluhur.ac.id ${ }^{2}$

\begin{abstract}
Timeliness of the publication of financial statements is one of the important aspects in presenting relevant information. This study aims to analyze the effect of financial factors proxied by liquidity, leverage and non-financial factors proxied by company age, public ownership on the timeliness of financial statement publications. This study uses secondary data with a sample of 38 mining companies listed on the Indonesia Stock Exchange for the period 2015 - 2019. The sampling method used is the purposive sampling method with the data analysis method in this study is logistic regression. The results of this study indicate that the age of the company affects the timeliness of financial reporting, while liquidity, leverage and public ownership do not affect the timeliness of the publication of financial statements.
\end{abstract}

Keywords: liquidity, leverage, company age, public ownership, timeliness of financial reporting

\section{ABSTRAKSI}

Ketepatan waktu publikasi laporan keuangan adalah salah satu aspek penting dalam menyajikan informasi yang relevan. Penelitian ini bertujuan untuk menganalisis pengaruh faktor keuangan yang diproksikan dengan likuiditas, leverage dan faktor non keuangan yang diproksikan dengan umur perusahaan, kepemilikan publik terhadap ketepatan waktu publikasi laporan keuangan. Penelitian ini menggunakan data sekunder dengan sampel 38 perusahaan pertambangan yang terdaftar di Bursa Efek Indonesia periode 2015 - 2019. Metode pengambilan sampel yang digunakan adalah metode purposive sampling dengan metode analisis data dalam penelitian ini adalah regresi logistik. Hasil penelitian ini menunjukkan bahwa umur perusahaan berpengaruh terhadap ketepatan waktu pelaporan keuangan, sedangkan likuiditas, leverage dan kepemilikan publik tidak berpengaruh terhadap ketepatan waktu publikasi laporan keuangan.

Kata Kunci: likuiditas, leverage, umur perusahaan, kepemilikan publik, ketepatan waktu publikasi laporan keuangan 


\section{PENDAHULUAN}

Laporan keuangan adalah catatan hasil informasi keuangan perusahaan yang dapat digunakan oleh pihak-pihak tertentu seperti investor, kreditor, pemerintah, pelanggan, pemasok dan lain- lain untuk pengambilan keputusan suatu perusahaan dan menggambarkan kinerja perusahaan dalam suatu periode. Jika laporan keuangan perusahaan diinformasikan secara akurat dan pihak yang perlu mengambil keputusan diinformasikan pada waktu yang tepat, itu akan baik untuk mereka. Tujuan akuntansi adalah untuk memberikan informasi yang tepat waktu dan relevan kepada pihak yang berkepentingan. Saat membuat keputusan, akuntan harus memiliki etika profesional, tanggung jawab profesional, integritas dan etika untuk memastikan bahwa informasi yang diberikan dapat diandalkan (Warren dkk 2015). Menurut PSAK No. 1 (revisi 2017), tujuan laporan keuangan adalah untuk memberikan informasi tentang status keuangan perusahaan, kinerja keuangan dan perubahan status keuangan, yang berguna bagi banyak orang untuk mengambil keputusan ekonomi Jika informasi yang relevan diperoleh tepat waktu sebelum pengguna kehilangan kesempatan atau kemampuan untuk mempengaruhi keputusan yang akan dibuat, informasi tersebut akan berguna bagi pihak-pihak yang membutuhkan.

Ketepatan waktu publikasi laporan keuangan adalah salah satu aspek berguna dalam menyajikan informasi yang relevan. Sangat berguna jika informasi keuangan dilaporkan kepada pihak - pihak yang membutuhkan secara tepat waktu. Di sisi lain, jika laporan keuangan tidak informasikan tepat waktu, manfaat laporan keuangan menjadi kurang bermanfaat. Jika data tidak diberitahukan tepat waktu, nilai data dalam pengambilan keputusan akan menurun. Setiap perusahaan yang tercatat di Bursa Efek Indonesia wajib menyampaikan laporan keuangan yang disusun sesuai dengan standar akuntansi keuangan dan diaudit secara tepat waktu dan mengatur kepatuhan dengan persyaratan Indonesia untuk penyampaian laporan keuangan publik tepat waktu dalam Undang-undang Nomor. 8 tahun 1995 mengatur bahwa jika suatu perusahaan terlambat menyampaikan laporan keuangannya, maka akan dikenakan sanksi administratif dan denda sesuai dengan undang-undang. Sanksi dan denda dikenakan kepada perusahaan yang menyampaikan laporan keuangan setelah batas waktu yang ditetapkan oleh Bursa Efek Indonesia, tujuannya agar investor dapat memperoleh informasi keuangan yang dibutuhkan untuk mengambil keputusan investasi dengan lebih cepat. Menurut Keputusan Ketua Badan Pengawas Pasar Modal dan Lembaga Keuangan Nomor KEP431/BL/2012, Peraturan Nomor X.K.6 pada tanggal 1 Agustus 2012 yang menyatakan bahwa setiap perusahaan publik yang terdaftar di Bursa Efek Indonesia (BEI) diwajibkan 
menyampaikan laporan keuangan tahunan yang disertai dengan laporan audit independen kepada Badan Pengawas Pasar Modal selambat-lambatnya pada akhir bulan keempat (120 hari).

Ketepatan waktu pelaporan keuangan juga diatur dalam peraturan Otoritas Jasa Keuangan No 44/POJK.04/2016 Tentang laporan lembaga penyampaian serta penyelesaian Pasal 7 (1) Laporan keuangan tengah tahunan wajib di beritahukan kepada Otoritas Jasa Keuangan paling lambat 60 (enam puluh) hari sejak tanggal akhir periode. (2) Laporan keuangan tahunan wajib disampaikan kepada Otoritas Jasa Keuangan dalam jangka waktu 90 (sembilan puluh) hari sejak tanggal akhir tahun buku. Sesuai dengan ketentuan II.6.1. Peraturan Bursa Nomor 1-H tentang Sanksi Jika perusahaan melanggar peraturan Bursa Efek Indonesia karena keterlambatan penyampaian laporan keuangan maka akan mendapatkan sanksi mulai dari Peringatan tertulis I hingga Suspensi saham yang beredar berikut dengan dendanya, sanksi yang diberikan Bursa Efek Indonesia diantaranya Peringatan tertulis I, atas keterlambatan penyampaian keuangan sampai dengan 30 hari kalender terhitung sejak batas penyampaian Laporan keuangan. Serta berdasarkan ketentuan II.6.2 Peraturan Bursa No. I-H tentang sanksi, Peringatan tertulis II atas keterlambatan penyampaian keuangan sampai dengan 31- 60 hari kalender sejak batas penyampaian Laporan keuangan dengan denda Rp. 50.000.000,- (lima puluh juta rupiah) dan berdasarkan ketentuan II.6.3 Peraturan bursa No. I-H tentang sanski, Peringatan tertulis III atas keterlambatan penyampaian keuangan sampai dengan 61-90 hari kalender sejak batas penyampaian Laporan Keuangan dengan denda Rp. 150.000.000,- (seratus lima puluh juta rupiah) dan berdasarkan ketentuan II.6.4 Peraturan No. I-H, terdapat sanksi suspensi atas keterlambatan penyampaian keuangan sampai dengan 91 hari kalender sejak batas penyampaian Laporan keuangan serta hal tersebut juga berlaku untuk perusahaan yang telah menyampaikan laporan keuangan, tetapi tidak membayar denda.

Berdasarkan sanksi peraturan di atas masih ada perusahaan yang terlambat dalam penyampaian laporan keuangan. Pada tahun 2015 Bursa Efek Indonesia menyatakan sampai tanggal 29 Juni 2019 terdapat 18 Perusahaan tercatat yang belum menyampaikan Laporan Keuangan Audit per 31 Desember 2015 dan/atau belum melakukan pembayaran denda atas keterlambatan penyampaian laporan keuangan (www.idx.co.id) dan pada tahun 2016 Bursa Efek Indonesia menyatakan hingga tanggal 29 Juni 2017 terdapat 17 Perusahaan yang belum menyampaikan Laporan Keuangan Auditan per 31 Desember 2016 dan/belum melakukan pembayaran denda atas keterlambatan penyampaian laporan keuangan (www.idx.co.id) Kemudian pada Tahun 
2017 Bursa Efek Indonesia menyatakan hingga tanggal 29 Juni 2018 terdapat 10 Perusahaan yang belum menyampaikan Laporan Keuangan Laporan Keuangan Auditan per 31 Desember 2017 dan/belum melakukan pembayaran denda atas keterlambatan penyampaian Laporan dan (www.idx.co.id) Kemudian pada Tahun 2018 Bursa Efek Indonesia menyatakan hingga tanggal 29 Juni 2019 terdapat 10 Perusahaan yang belum menyampaikan menyampaikan Laporan Keuangan Tahunan per 31 Desember 2018 dan/atau belum melakukan pembayaran denda atas keterlambatan penyampaian Laporan Keuangan (www.idx.co.id) Kemudian pada tahun 2019 menyatakan sampai dengan tanggal 30 Juli 2020 terdapat 26 Perusahaan Tercatat belum menyampaikan Laporan Keuangan Auditan yang berakhir per 31 Desember 2019 dan/atau melakukan pembayaran denda atas keterlambatan penyampaian Laporan Keuangan (www.cnnindonesia.com). Berikut ini, gambaran mengenai banyaknya perusahaan yang mendapatkan Surat Peringatan Tertulis I sampai dengan perusahaan yang mendapatkan Suspensi dari Bursa Efek Indonesia periode 2015- 2019 adalah sebagai berikut:

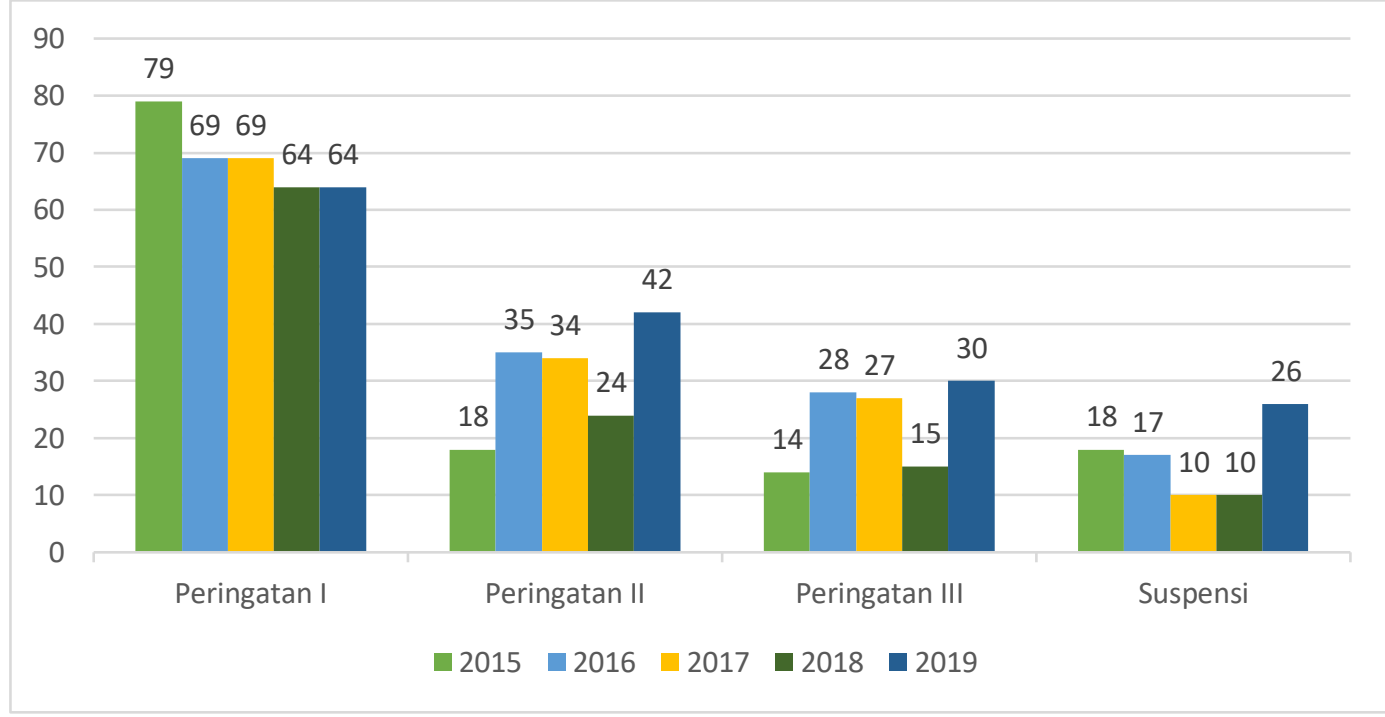

Sumber: Bursa Efek Indonesia

\section{Gambar 1. Perusahaan yang Dikenakan Peringatan Tertulis I hingga Suspensi data dari Bursa Efek Indonesia periode 2015 - 2019}

Berdasarkan data di atas dari tahun 2015 sampai tahun 2019 meski mendapatkan peringatan tertulis I sampai dengan suspensi masih banyak perusahaan yang terlambat menyampaikan laporan keuangan. Penerbitan peraturan ini mencerminkan bahwa pihak pembuat peraturan cukup serius menanggapi kasus ketidakpatuhan dalam hal penyampaian laporan keuangan yang auditan. Bagi perusahaan yang telah terdaftar di Bursa Efek Indonesia, sebaiknya perusahaan tersebut menghindari situasi ini. Keterlambatan penyampaian laporan keuangan yang telah diaudit dapat mengakibatkan 
menurunnya kepercayaan investor, selain itu dengan adanya ketidakpatuhan perusahaan dalam menyampaikan laporan keuangan auditan dapat mempengaruhi image atau citra perusahaan dimata publik.

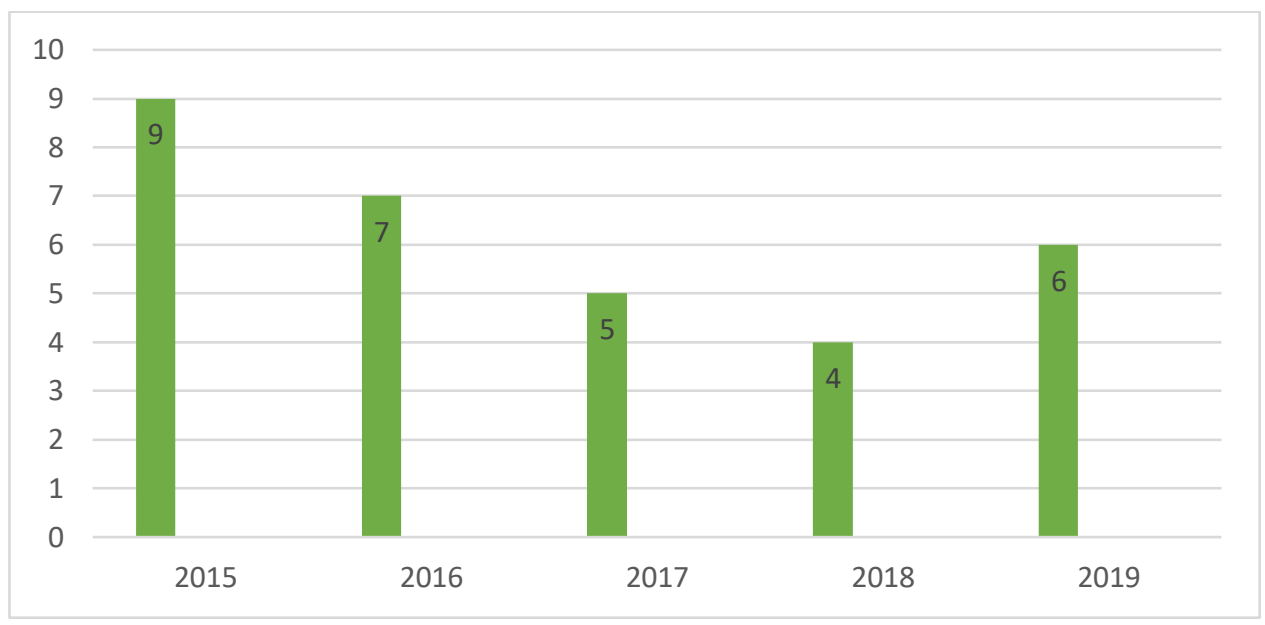

Sumber : Bursa Efek Indonesia

Gambar 2 . Keterlambatan Penyapaian Laporan Keuangan pada Perusahaan Pertambangan Tahun 2015 - 2019

Berdasarkan data di atas dapat diketahui bahwa perusahaan pertambangan merupakan salah satu industri dengan jumlah perusahaan terbanyak yang melakukan keterlambatan penyampaian keuangan kepada Bursa Efek Indonesia. Pasalnya, perusahaan pertambangan merupakan salah satu perusahaan terbanyak di Bursa Efek Indonesia.

Terdapat dua kelompok faktor yang bisa mempengaruhi ketepatan waktu penyampaian laporan keuangan yaitu factor keuangan dan factor non keuangan. Faktor keuangan itu antara lain adalah likuiditas, Likuiditas adalah kecakapan suatu kegiatan usaha dalam memenuhi utang berjangka pendek pada waktu yang ditetapkan (Choiruddin, 2015) dalam (Jessica dan Vargo, 2019) ketepatan waktu penyampaian laporan keuangan tidak dipengaruhi secara signifikan oleh likuiditas terhadap ketepatan waktu penyampaian laporan keuangan. likuiditas bukan salah satu fokus kabar baik untuk pengguna laporan keuangan. Kewajiban jangka pendek yang cukup besar dalam suatu perusahaan, yang kemudian tidak bisa melaksanakan pembayaran pada saat jatuh tempo, sehingga dapat saja mengakibatkan kewajiban jangka pendek yang dimiliki berubah jadi jangka panjang. Hasil dari penelitian dari (Jessica dan Vargo, 2019). Tidak hanya Likuiditas saja, faktor keuangan lainnya yaitu leverage. Leverage juga dapat mempengaruhi Ketepatan waktu pelaporan keuangan, leverage keuangan (financial leverage) ialah pemakaian utang untuk meningkatkan laba. Leverage memperbesar keberhasilan (laba) serta kegagalan (rugi) manajerial. Dalam perihal ini leverage ratio 
(rasio solvabilitas) ialah rasio yang digunakan untuk mengukur sejauh mana aset perusahaan dibiayai dengan utang. Leverage ialah rasio yang menggambarkan keadaan model perusahaan. Dalam hal ini menyatakan bahwa leverage berpengaruh terhadap ketepatan waktu penyampaian laporan keuangan perusahaan, long term debt to equity ratio tepat untuk dijadikan tolak ukur untuk ketepatan waktu penyampaian perusahaan. Sebab apabila nilai long term debt to equity ratio rendah maka bisa mencerminkan jika perusahaan tersebut memperoleh kepercayaan investor. Hasil dari riset dari (Ardian Dwi Prasetyo).

Faktor lainnya yang bisa mempengaruhi ketepatan waktu publikasi laporan keuangan ialah faktor non keuangan yang antara lain diukur dengan umur perusahaan. Umur perusahaan membuktikan kredibilitas ataupun reputasi perusahaan dimata publik. Apabila perusahaan sudah lama berdiri umumnya dianggap mempunyai kinerja yang baik sehingga memunculkan keyakinan publik. Perusahaan yang sudah lama berdiri, secara langsung membuktikan bahwa perusahaan mampu bertahan serta meraih laba dalam berbagai kondisi ekonomi. Perusahaan yang memiliki umur yang relatif lebih, umumnya lebih baik mengumpulkan, memproses serta menciptakan informasi, hal itu disebabkan perusahaan telah mempunyai jam kerja yang banyak. Sebaliknya perusahaan yang lebih muda lebih rentan terhadap kegagalan sebab minimnya pengalaman (Iyoha, 2012) dalam (Valentina dan Gayatri, 2018) Umur perusahaan berpengaruh positif terhadap ketepatan waktu pelaporan keuangan. Perihal ini berarti perusahaan mapan yang mempunyai umur lebih tua cenderung lebih terampil dalam pengumpulan, pemrosesan serta menghasilkan informasi pada saat dibutuhkan sebab pengalaman belajar dan bisnis (Valentina serta Gayatri, 2018).

Selain umur perusahaan, kepemilikan publik dianggap dapat mempengaruhi ketepatan waktu pelaporan keuangan. Kepemilikan Publik merupakan pemegang saham yang bukan dari pihak manajemen melainkan yang beredar dalam masyarakat. Menurut Hilmi dan Ali (2008) Kepemilikan publik adalah kepemilikan masyarakat umum (bukan institusi yang signifikan) terhadap saham perusahaan publik, kepemilikan publik diukur dengan melihat melihat seberapa banyak saham yang dimiliki publik atau masyarakat dalam suatu perusahaan. Kepemilikan publik juga mendorong pengawasan secara lebih mendetail dan ketat, menjaga tindakan yang mampu merugikan baik kepemilikan institusional ataupun kepemilikan publik sendiri. Kepemilikan publik berpengaruh positif terhadap ketepatan waktu publikasi laporan keuangan Hal ini karena pemilik eksternal perusahaan memiliki kekuatan yang besar untuk meminta manajemen dalam menyajikan informasi secara tepat waktu, karena ketepatan waktu pelaporan keuangan 
mempengaruhi pengambilan keputusan ekonomi. Hasil penelitian dari (Supartini, Endiana, dan Kumalasari 2021).

\section{KERANGKA TEORITIS DAN HIPOTESIS}

\section{Tinjauan Pustaka}

Menurut Agency Theory, principal sebagai pemilik memberi kewewenangan kepada agen atau manajer mengenai pembuatan keputusan yang terbaik bagi principal dengan mengutamakan kepentingan dalam mengoptimalkan laba perusahaan sehingga meminimalisir beban, termasuk beban pajak dengan melakukan penghindaran pajak. Ketepatan waktu publikasi laporan keuangan memegang peranan penting bagi investor, karena laporan keuangan dapat memberikan informasi penting tentang perusahaan. Informasi tersebut dapat dinyatakan secara kuantitatif dalam satuan mata uang dan prospek masa depan perusahaan, berdasarkan nilai pengguna yang sangat besar. Ketika transfer kekayaan pemegang saham tetap meningkat, investor menggunakan informasi tentang laporan keuangan untuk mengukur kemampuan modal yang diinvestasikan di semua aset untuk menghasilkan keuntungan.

Ketika perusahaan memperoleh keuntungan, manajemen perusahaan akan mengirimkan sinyal kepada investor, meminta mereka untuk mendukung kelangsungan posisi manajemen saat ini dan kompensasi manajemen yang lebih tinggi. Perusahaan yang mengalami keuntungan maka kepercayaan kepada manajemen akan meningkat, sehingga manajer secara sukarela mengungkapkan laporan keuangannya dan segera memberikan informasi ketika kinerja suatu perusahaan sedang baik, sebaliknya ketika kinerja perusahaan tidak baik manajemen mungkin akan mengulur waktu untuk mengumumkan laporan keuangannya atau lebih memilih membatasi akses informasi akuntansi. Keadaan ini akan menimbulkan situasi yang disebut asimetri informasi (information asymmetry), dimana pemilik perusahaan tidak memiliki informasi yang cukup tentang kinerja manajemen dan tidak pernah dapat mengetahui bagaimana manajemen dapat memberikan kontribusi kepada perusahaan. Salah satu elemen kunci dari teori agensi adalah bahwa pemilik perusahaan dan manajemen memiliki preferensi atau tujuan yang berbeda karena semua individu bertindak atas kepentingan pribadi mereka sendiri. Salah satu cara untuk mengurangi dampak asimetri informasi adalah dengan melakukan pengawasan terhadap aktivitas manajemen. Agency Theory muncul karena adanya perbedaan tujuan antara pemilik (pemegang saham) dan manajemen (manajer) (Anthony dan Robert N, 2012). Hubungan keagenan dapat terjadi pada satu orang atau lebih, di mana pemegang saham memberikan tugas kepada pihak 
manajemen untuk mengerjakan beberapa tugas yang diharapkan oleh investor (Jensen, MC dan Meckling, 1976). Dalam hal ini seorang manajer bertugas untuk memaksimalkan nilai perusahaan (Yuniati, 2016). Agency theorymenjelaskan bahwa setiap individu yang terlibat dalam hubungan keagenan pastinya mempunyai prioritas yang berbeda diantara masing- masing individu. Investor tidak memiliki prospek dan informasi internal dikarena perusahaan diolah oleh manajemen (Borolla, 2011). Tujuan utama perusahaan adalah memberikan informasi secara cepat dan tepat waktu kepada pemilik terkait dengan tingkat kemakmuran yang dapat diberikan oleh manajemen perusahaan kepada pemiliknya.

Teori kepatuhan (compliance theory) menurut Lunenburg (2012) dalam Wiryakriyana dan Widhiyani (2017) merupakan metode struktur organisasi yang mengintegrasikan ide-ide dari model klasik dan partisipasi manajemen. Menurut teori ini mematuhi dapat berarti taat, tunduk, patuh pada ajaran atau aturan. Teori kepatuhan mendorong individu untuk lebih mematuhi hukuman dan peraturan yang berlaku, seperti halnya perusahaan yang berusaha untuk menyampaikan laporan keuangan secara tepat waktu. Tepat waktu diartikan bahwa informasi harus disampaikan secepat mungkin agar dapat digunakan sebagai dasar untuk membantu dalam pengambilan Keputusan keputusan ekonomi dan menghindari tertundanya pengambilan keputusan tersebut (Baridwa:1997) dalam Sanjaya dan Wirawati (2016). Laporan yang tepat waktu adalah laporan keuangan yang di sampaikan sesuai dengan peraturan BAPEPAM Nomor KEP431/BL/2012. Untuk tahun 2015 perusahaan yang menyampaikan laporan keuangannya sebelum atau sampai tanggal 31 April diklasifikasikan bahwa perusahaan tersebut tepat waktu dalam menyampaikan laporan keuangannya ke BAPEPAM. Sedangkan untuk tahun 2016 - 2019 ketepatan waktu didasarkan pada Peraturan OJK No 44/POJK.04/2016 perusahaan dapat dinyatakan tepat waktu dalam pelaporan keuangan apabila perusahaan dapat menyampaikan laporan keuangannya sebelum atau sampai dengan tanggal 31 Maret.

\section{Pengembangan Hipotesis}

\section{Pengaruh Likuiditas terhadap Ketepatan Waktu Publikasi Laporan Keuangan}

Likuiditas adalah rasio yang menggambarkan kemampuan perusahaan dalam memenuhi kewajiban (utang) jangka pendek (Kasmir, 2019). Tingkat likuiditas yang tinggi pada sebuah perusahaan menunjukan bahwa perusahaan tersebut dapat memenuhi kewajiban jangka pendeknya dengan baik, sedangkan tingkat likuiditas yang rendah menunjukan bahwa perusahaan tersebut belum mampu memenuhi kewajiban 
jangka pendeknya dengan baik. Perusahaan yang mempunyai tingkat likuiditas yang tinggi menunjukan kabar baik (good news) bagi perusahaan, hal ini nantinya akan mempengaruhi perusahaan untuk menyampaikan laporan keuangan dengan tepat waktu karena akan membuat reaksi pasar menjadi positif terhadap perusahaan. Berdasarkan uraian di atas, maka hipotesis penelitian ini adalah:

H1 : Likuiditas berpengaruh terhadap ketepatan waktu publikasi laporan keuangan

\section{Pengaruh Leverage terhadap Ketepatan Waktu Publikasi Laporan Keuangan}

Pada penelitian yang dilakukan Prastyo (2016), Nurfauziah (2016), Janrosl (2018) dikemukakan bahwa leverage berpengaruh terhadap ketepatan waktu pelaporan keuangan. Perusahaan dengan leverage tinggi berarti mereka sangat bergantung pada pinjaman eksternal untuk membiayai perusahaan mereka. Rasio leverage yang tinggi mencerminkan risiko keuangan perusahaan yang tinggi. Risiko keuangan yang tinggi menunjukkan bahwa perusahaan sedang mengalami kesulitan keuangan, kemungkinan bahwa perusahaan tersebut tidak dapat melunasi kewajiban hutangnya baik pokok maupun bunganya.

Berdasarkan uraian di atas, maka hipotesis penelitian ini adalah:

$\mathrm{H} 2$ : Leverage berpengaruh terhadap ketepatan waktu publikasi laporan keuangan

\section{Pengaruh Umur Perusahaan terhadap Ketepatan Waktu Publikasi Laporan Keuangan}

Penelitian yang dilakukan Valentina dan Gayatri (2018), Purba (2020), Putri (2019) mengemukakan bahwa umur perusahaan berpengaruh terhadap ketepatan waktu pelaporan keuangan. Perusahaan yang telah lama terdaftar di Bursa Efek Indonesia, membuat para akuntannya lebih jeli dan peka mengamati hal-hal yang mengakibatkan penundaan penyampaian laporan tahunannya ke Bursa Efek Indonesia. Oleh karena itu perusahaan akan lebih efisien memanfaatkan waktu dalam mengumpulan, memproses dan mempublikasi informasi ketika dibutuhkan karena lebih berpengalaman.

Berdasarkan uraian di atas, maka hipotesis dalam penelitian ini adalah:

H3: Umur perusahaan berpengaruh terhadap ketepatan waktu publikasi laporan keuangan 


\section{Pengaruh Kepemilikan Publik terhadap Ketepatan Waktu Publikasi Laporan Keuangan}

Hasil penelitan dari Supartini, Endiana, dan Kumalasari (2021), Novelia dan Rahayu (2016) dan Sembiring (2016) menyatakan bahwa Kepemilikan publik berpengaruh terhadap ketepatan waktu pelaporan keuangan. Pemilik perusahaan dari pihak luar mempunyai kekuatan yang besar untuk menekan manajemen dalam menyajikan laporan keuangan secara tepat waktu, karena ketepatan waktu pelaporan keuangan akan mempengaruhi pengambilan keputusan ekonomi. Pemilik pihak luar mempunyai kepentingan untuk mengetahui tingkat pengembalian atas investasi mereka. Dengan demikian, perusahaan dengan proporsi kepemilikan publik yang besar cenderung tepat waktu dalam pelaporan keuangannya.

Berdasarkan uraian di atas, maka hipotesis dalam penelitian ini adalah:

H4 : Kepemilikan publik berpengaruh terhadap ketepatan waktu publikasi laporan keuangan

\section{METODE PENELITIAN}

\section{Populasi dan Sampel Penelitian}

Penelitian ini merupakan penelitian kuantitatif dengan teknik analisis data adalah regresi logistik yang menggunakan data sekunder berupa data penelitian dari laporan keuangan perusahaan sektor pertambangan yang dipublikasikan di Bursa Efek Indonesia tahun 2015 sampai dengan tahun 2020. Oleh karena itu maka populasi yang digunakan sebagai observasi dalam penelitian ini adalah perusahaan pertambangan yang terdaftar di Bursa Efek Indonesia (BEI) Periode tahun 2015 - 2019 yang berjumlah 49 perusahaan dengan sample sebanyak 38 perusahaan. Adapun teknik penarikan sampel dalam penelitian adalah purposive sampling sebagai berikut:

Tabel 1. Penarikan Sampel Penelitian

\begin{tabular}{|c|c|c|}
\hline No & Kriteria & Total \\
\hline 1 & $\begin{array}{l}\text { Perusahaan sektor pertambangan yang terdaftar di BEI } \\
\text { periode } 2015-2019\end{array}$ & 49 \\
\hline \multicolumn{3}{|c|}{ Yang Tidak Memenuhi Kriteria: } \\
\hline 2 & $\begin{array}{l}\text { Perusahaan sektor pertambangan yang di delisting dari } \\
\text { BEI periode } 2015-2019\end{array}$ & (2) \\
\hline 3 & $\begin{array}{l}\text { Perusahaan sektor pertambangan yang tidak melaporkan } \\
\text { laporan keuangan di BEI diantara periode } 2015-2019\end{array}$ & (9) \\
\hline \multicolumn{2}{|r|}{$\begin{array}{l}\text { Perusahaan yang lulus kriteria dan dijadikan sebagai } \\
\text { sample penelitian }\end{array}$} & 38 \\
\hline
\end{tabular}




\section{Operasional Variabel}

\section{Ketepatan waktu publikasi laporan keuangan}

Ketepatan waktu dalam publikasi laporan keuangan ke publik sangat dibutuhkan dan oleh karena itu tiap-tiap perusahaan diharapkan tidak melakukan penundaan dalam penyajian dan publikasi laporan keuangannya. Salah satu cara untuk mengukur transparansi dan kualitas pelaporan keuangan adalah ketepatan waktu, rentang waktu antara tanggal laporan perusahaan dan tanggal ketika informasi keuangan diumumkan ke publik berhubungan dengan kualitas informasi keuangan yang dilaporkan. Ketepatwaktuan penyampaian dan publikasi laporan keuangan merupakan salah satu karakteristik penting dalam mendukung relevansi informasi keuangan. Informasi berpotensi kehilangan relevansinya karena usia dan perpanjangan waktu keterlambatan penyajian informasi laporan keuangan, sehingga menjadi informasi yang kurang berguna untuk pengambilan keputusan ekonomi. Tepat waktu diartikan bahwa informasi harus disampaikan secepat mungkin agar dapat digunakan sebagai dasar untuk membantu dalam pengambilan Keputusan-keputusan ekonomi dan menghindari tertundanya pengambilan keputusan tersebut (Baridwa:1997) dalam Sanjaya dan Wirawati (2016). Ketepatan waktu publikasi laporan keuangan adalah salah satu karakteristik penting bagi laporan keuangan dimana laporan keuangan yang dilaporkan secara tepat waktu akan mengurangi informasi asimetris (Imaniar dan Kurnia, 2016). Ketepatan waktu merupakan informasi yang harus disediakan saat dibutuhkan, terutama didalam setiap pengambilan keputusan bisnis (Hery, 2016: 167). Dari sebagian pendapat diatas, dapat disimpulkan bahwa ketepatan waktu publikasi laporan keuangan adalah informasi laporan keuangan disajikan secara relevan karena informasi laporan keuangan yang disampaikan dan dipublikasikan secara tepat waktu dapat dijadikan sebagai dasar pengambilan keputusan bagi para pengguna laporan keuangan. Indikator yang digunakan untuk mengukur skala ketepatan waktu pelaporan keuangan adalah sebagai berikut, Dewayani (2017) :

Kode 1 = Perusahaan yang tepat waktu dalam publikasi laporan keuangan di BEI

Kode $0=$ Perusahaan yang tidak tepat waktu dalam publikasi laporan keuangan di BEI

\section{Likuiditas}

Likuiditas menurut Kasmir (2019) adalah rasio yang menggambarkan kemampuan perusahaan dalam memenuhi kewajiban (utang) jangka pendek. Artinya apabila perusahaan ditagih, perusahaan akan mampu untuk memenuhi utang tersebut 
terutama utang yang sudah jatuh tempo. Pengukuran likuiditas dalam penelitian ini menggunakan current ratio dengan membandingkan besaran total aset lancar dengan hutang lancar (Kasmir, 2019).

$$
\text { Current ratio }=\frac{\text { Total Aset Lancar }}{\text { Total Utang Lancar }}
$$

\section{Leverage}

Leverage menurut Fahmi (2015) leverage adalah suatu rasio pengukuran yang mengukur seberapa besar kegiatan atau aktivitas usaha perusahaan dibiayai dengan utang. Penggunaan utang yang terlalu tinggi akan membahayakan perusahaan karena perusahaan akan masuk dalam kategori extreme leverage (utang ekstrim) yaitu perusahaan terjebak dalam tingkat utang yang tinggi dan sulit untuk melepaskan beban utang tersebut. Pada penelitian ini, pengukuran leverage menggunakan rasio utang terhadap ekuitas (Debt to Equity Ratio) dimana rasio ini berfungsi untuk mengetahui setiap rupiah modal sendiri yang dijadikan untuk jaminan terhadap utang (Kasmir 2019).

$$
\text { Debt to equity ratio }=\frac{\text { Total Hutang }}{\text { Total Ekuitas }}
$$

\section{Umur Perusahaan}

Umur perusahaan menggambarkan seberapa lama perusahaan tersebut berdiri dan dapat bertahan dalam kegiatan usahanya. Semakin lama umur suatu perusahaan, maka akan semakin berpengalaman sehingga perusahaan tersebut mampu mengantisipasi resiko yang mungkin dapat terjadi. Pengalaman perusahaan dalam menjalankan aktivitas operasional perusahaannya tersebut tentu dapat berimplikasi kepada laba yang dapat diperoleh perusahaan. Umur perusahaan merupakan salah satu hal yang dipertimbangkan investor dalam menanamkan modalnya, umur perusahaan mencerminkan perusahaan tetap survive dan menjadi bukti bahwa perusahaan mampu bersaing dan dapat mengambil kesempatan bisnis yang ada dalam perekonomian. Perusahaan yang mempunyai umurnya yang relatif lama, pada umumnya perusahaan itu lebih tepat waktu dalam menghasilkan informasi, hal itu dikarenakan perusahaan sudah memiliki pengalaman dan pemahaman yang lebih baik dalam proses penyiapan inforamsi keuangan secara tepat waktu, sedangkan perusahaan yang umurnya relatif lebih muda lebih rentan terhadap kegagalan dalam penyiapan informasi keuangan secara tepat waktu karena kurangnya pengalaman (Putra dan Ramantha, 2015).

Umur Perusahaan = Tahun berdirinya perusahaan sampai dengan tahun yang dijadikan penelitian 


\section{Kepemilikan Publik}

Kepemilikan publik menurut Hilmi dan Ali (2008) dalam Utari dan Amin (2011) adalah kepemilikan masyarakat umum bukan institusi yang signifikan terhadap saham perusahaan publik. Dan menurut Wijayanti (2009) dalam Yunitasari (2014) Kepemilikan publik adalah proporsi atau jumlah kepemilikan saham yang dimiliki oleh publik atau masyarakat umum yang tidak memiliki hubungan istimewa dengan perusahaan sehinggga oleh karena itu kepemilikan publik merupakan suatu proporsi kepemilikan saham suatu entitas perushaaan yang dimiliki oleh pihak masyarakat yang dihitung dalam persentase tertentu.

$$
\text { Kepemilikan Publik }=\frac{\text { Saham Pihak Luar }}{\text { Total Saham }} \text { X } 100 \%
$$

\section{Model Penelitian}

Model penelitian yang digunakan untuk menganalisis pengaruh variabel independen terhadap variabel dependen adalah model regresi logistik dimana variabel dependen yang berupa data nominal dan independen berupa data rasio di analisis uji dengan regresi logistik (Binary Logistic Regresion). Model regresi logistik yang digunakan dalam penelitian adalah sebagai berikut:

$\operatorname{Ln} \frac{\text { Time }}{\text { 1-Time }}=\beta 0+\beta 1 \mathrm{CR}+\beta 2 \mathrm{DER}+\beta 3 \mathrm{AGE}+\beta 4 \mathrm{KP}+\varepsilon$

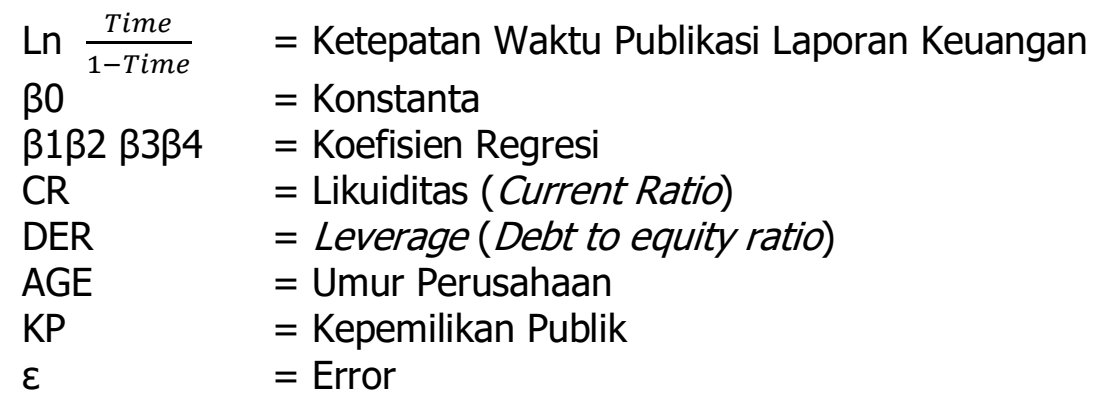

Adapun kerangka model penelitian yang dijabarkan dalam bentuk diagram jalur yang menggambarkan hubungan antar variabel berdasarkan teknik analisis yang dilakukan diungkapkan sebagai berikut: 


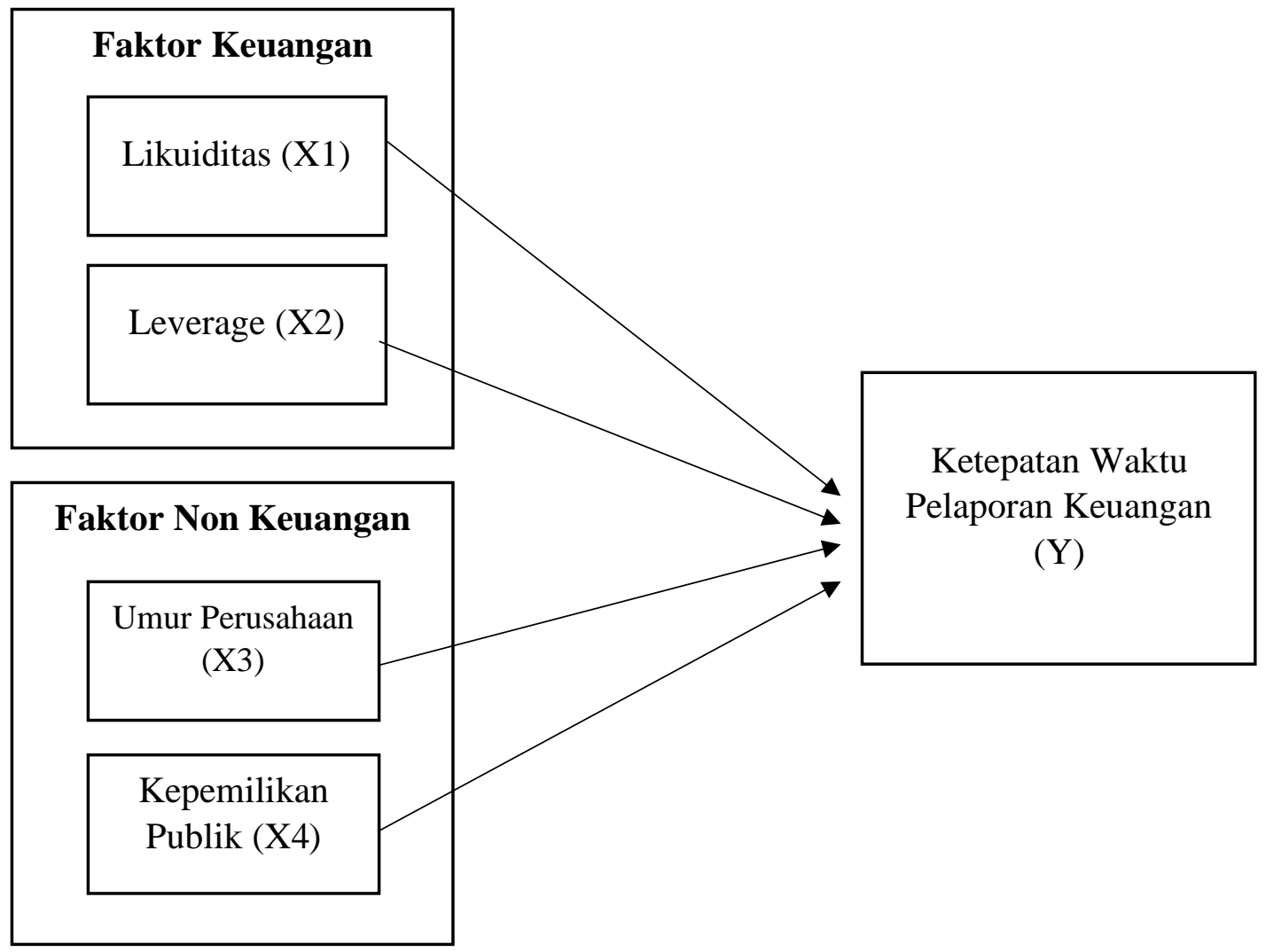

Gambar 3. Kerangka Model Penelitian

\section{PEMBAHASAN HASIL PENELITIAN}

\section{Analisis Pengujian Data Penelitian}

\section{Statistik Deskriptif}

Analisis statistik deskriptif dalam penelitian ini mengambarkan distribusi frekuensi, pengukuran tendensi pusat, dan pengukuran variabilitas berupa angka seperti mean, median, standar deviasi yang dikaitkan dengan pengaruh variabel independen terdiri dari likuiditas, leverage, umur perusahaan, kepemilikan publik terhadap variabel dependennya ketepatan waktu (timeliness) publikasi laporan keuangan.

Tabel 2. Statistik Deskriptif

\begin{tabular}{llllll}
\hline & & & & & Std. \\
& $\mathrm{N}$ & Minimum & Maximum & Mean & Deviation \\
\hline LIKUIDITAS X1 & 190 &, 00 & 47,14 & 2,2191 & 3,95703 \\
LEVERAGE X2 & 190 & $-15,82$ & 34,06 & 1,4642 & 4,10371 \\
UMUR X3 & 190 & 3,00 & 51,00 & 26,3947 & 12,33041 \\
KEPEMILIKAN PUBLIK X4 & 190 &, 02 &, 85 &, 2951 &, 18503 \\
KETEPATAN WAKTU LK Z & 190 &, 00 & 1,00 &, 7316 &, 44431 \\
Valid N (listwise) & 190 & & & & \\
\hline
\end{tabular}

Sumber: Hasil Uji, 2020 


\section{Uji Kelayakan Model Penelitian}

Uji Kelayakan Model dalam penelitian ini diukur dengan menggunakan pengujian omnibus test of model coefficients, dan uji hosmer lemeshow. Pada uji omnibus test of model coefficients diperoleh penjelasan bahwa pengaruh dari seluruh variabel independen terhadap variabel dependen layak untuk dilakukan.

Tabel 3. Uji Kelayakan Model Penelitian

\begin{tabular}{llccl}
\hline No & $\begin{array}{c}\text { Uji Kelayakan } \\
\text { Model }\end{array}$ & $\begin{array}{c}\text { Syarat } \\
\text { Angka } \\
\text { Sig. }\end{array}$ & $\begin{array}{c}\text { Angka Sig. } \\
\text { Hasil Uji }\end{array}$ & Keputusan \\
\hline 1 & $\begin{array}{l}\text { omnibus test of } \\
\text { model coefficients } \\
\text { hosmer lemeshow }\end{array}$ & $<0,05$ & 0,000 & $\begin{array}{l}\text { Memiliki kelayakan } \\
\text { terhadap model }\end{array}$ \\
2 & $>0,05$ & 0,856 & $\begin{array}{l}\text { Memiliki kelayakan } \\
\text { terhadap model }\end{array}$ \\
\hline
\end{tabular}

Sumber: Hasil Penelitian, 2020

Berdasarkan data pada tabel di atas pengujian ini diperoleh nilai signifikansi 0,000. Dengan nilai signifikansi kurang dari atau angkanya lebih kecil dari 0,05 berarti bahwa variabel independen yang terdiri dari faktor keuangan meliputi likuiditas dan leverage serta faktor non keuangan meliputi umur perusahaan dan kepemilikan publik berpengaruh secara simultan terhadap variabel dependen yaitu ketepatan waktu publikasi laporan keuangan dan memiliki kelayakan terhadap model dalam penelitian ini, sedangkan pada pengujian kelayakan model penelitian dengan uji hosmer lemeshow diperoleh hasil pengujiana pada tingkat signifikansi sebesar 0,856 lebih besar dari nilai signifikansi 0,05 yang dipersyaratkan sehingga hal ini berarti bahwa model regresi yang digunakan dalam penelitian ini layak digunakan untuk analisis selanjutnya, karena model dengan data observasinya tidak ada perbedaan.

\section{Uji Koefisien Determinasi}

Koefisien determinasi digunakan sebagai informasi mengenai kecocokan suatu model dan dihitung untuk mengetahui sejauh mana kecocokan sejumlah variabel bebas yaitu likuiditas, leverage, umur perusahaan, dan kepemilikan publik dalam sebuah model persamaan regresi logistik secara berbarengan mampu menjelaskan variabel tidak bebasnya yaitu ketepatan waktu publikasi laporan keuangan (timeliness).

\section{Tabel 4. Uji Koefisien Determinasi}

\begin{tabular}{|c|l|}
\hline $\begin{array}{c}\text { Uji Nagelkerke } \boldsymbol{R} \\
\text { Square }\end{array}$ & \multicolumn{1}{|c|}{ Kesimpulan } \\
\hline 0,559 & $\begin{array}{l}\text { Faktor keuangan dan faktor non keuangan dari } \\
\text { perusahaan sektor pertambangan yang } \\
\text { mempengaruhi ketepatan waktu publikasi laporan } \\
\text { keuangan dapat jelaskan sebesar 0,559 atau 55,9\% }\end{array}$ \\
\hline
\end{tabular}

Sumber: Hasil Penelitian, 2020 
Berdasarkan uji koefisien determinasi diperoleh angka Nagelkerke $R$ Square sebesar 0,559 atau 55,9\% yang berarti bahwa variabel faktor keuangan yang terdiri dari likuidtas dan leverage serta variabel faktor non keuangan terdiri dari umur perusahaan dan kepemilikan publik perusahaan sektor pertambangan yang mempengaruhi ketepatan waktu publikasi laporan keuangan dapat jelaskan sebesar 0,559 atau 55,9\% sedangkan sisanya sebesar 0,441 atau $44,1 \%$ dipengaruhi oleh variabel lain yang tidak di teliti dalam penelitian ini

\section{Model Regresi Hasil Pengujian Dalam Penelitian}

Berdasarkan hasil pengujian dengan menggunakan analisis regresi logistik diperoleh model regresi sebagai berikut:

Tabel 5. Hasil Uji Persamaan Regresi Logistik

\begin{tabular}{lc}
\multicolumn{1}{c}{ Variabel } & Nilai B dalam model regresi \\
\hline Likuiditas (X1) & $-0,148$ \\
Leverage (X2) & 0,977 \\
Umur Perusahaan (X3) & 0,195 \\
Kepemilikan Publik (X4) & 0,120 \\
Constant & $-5,010$ \\
\hline
\end{tabular}

Sumber: Hasil Penelitian, 2020

$$
\text { Ln } \frac{\text { Time }}{1-\text { Time }}=-5,010-0,148 \text { LKD }+0,977 \text { LEV }+0,195 \text { UMUR }-0,120 \mathrm{KP}+\varepsilon
$$

\section{Uji Hipotesis}

Uji hipotesis dalam penelitian menggunakan uji wald pada regresi logistik yang ditunjukkan dengan hasil sebagai berikut:

Tabel 6. Uji Hipotesis

\begin{tabular}{ccccc}
\hline No & Hipotesis & $\begin{array}{c}\text { Syarat } \\
\text { Angka Sig. }\end{array}$ & $\begin{array}{c}\text { Angka Sig. } \\
\text { Hasil Uji }\end{array}$ & Hasil Uji \\
\hline 1 & Hipotesis 1 & $<0,05$ & 0,450 & Ditolak \\
2 & Hipotesis 2 & $<0,05$ & 0,353 & Ditolak \\
3 & Hipotesis 3 & $<0,05$ & 0,016 & Diterima \\
4 & Hipotesis 4 & $<0,05$ & 0,961 & Ditolak \\
\hline
\end{tabular}

Sumber: Hasil Penelitian, 2020

Variabel Likuiditas yang diproksikan current ratio memiliki nilai signifikan sebesar 0,450 lebih tinggi dari 0,05 yang berarti hipotesa 1 ditolak, sehingga variabel likuiditas tidak berpengaruh terhadap ketepatan waktu publikasi laporan keuangan. Variabel Leverage yang diproksikan Debt to Equity Ratio memiliki nilai signifikan sebesar 0,353 lebih tinggi dari 0,05 berarti bahwa hipotesa 2 ditolak sehingga variabel leverage tidak berpengaruh terhadap ketepatan waktu publikasi laporan keuangan. Variabel Umur Perusahaan memiliki nilai signifikansi sebesar 0,016 lebih kecil dari 0,05 berarti bahwa 
Hipotesa 3 diterima sehingga variabel umur perusahan berpengaruh terhadap ketepatan waktu publikasi laporan keuangan. Variabel kepemilikan publik memiliki nilai signifikansi hasil uji sebesar 0,961 lebih besar angkanya dari 0,05 yang berarti bahwa hipotesa 4 ditolak dan variabel kepemilikan publik tidak berpengaruh terhadap ketepatan waktu publikasi laporan keuangan.

\section{Pembahasan dan Interpretasi Hasil Penelitian}

\section{Pengaruh Likuitas Terhadap Ketepatan Waktu Publikasi Laporan Keuangan}

Likuiditas yang diproksikan Current Liabilities memiliki nilai signifikan sebesar 0,450 lebih tinggi dari 0,05 berarti likuiditas tidak berpengaruh secara signifikan terhadap ketepatan waktu pelaporan keuangan. Tidak berpengaruhnya likuiditas terhadap ketepatan waktu publikasi laporan keuangan disebabkan ketepatan waktu publikasi laporan keuangan tidak semata-mata ditentukan oleh besar kecilnya tingkat likuiditas perusahaan. Perusahaan yang memiliki likuiditas tinggi atau rendah sama - sama ingin meyampaikan laporan keuangannya secara tepat waktu agar terhindar dari sanksi yang dikenakan oleh Bursa Efek Indonesia (BEI) dan Otoritas Jasa Keuangan (OJK).

\section{Pengaruh Leverage Terhadap Ketepatan Waktu Publikasi Laporan Keuangan}

Leverage yang diproksikan Debt to Equity Ratio memiliki nilai signifikan sebesar 0,353 lebih tinggi dari 0,05 berarti hipotesis 2 ditolak dan variabel leverage tidak berpengaruh secara signifikan terhadap ketepatan waktu pelaporan keuangan. Hasil penelitian ini menggambarkan bahwa tinggi atau rendahnya leverage keuangan perusahaan tidak mempengaruhi ketepatan waktu publikasi laporan keuangan. Perusahaan yang memiliki tingkat leverage yang tinggi ataupun yang memiliki tingkat leverage yang rendah sama-sama berkeinginan dan selalu berupaya untuk meningkatkan kepercayaan publik khususnya para kreditur dan calon kreditur. Salah satu upaya yang dilakukan guna menaikkan tingkat kepercayaan para kreditur dan calon kreditur tersebut adalah melalui publikasi laporan keuangan yang tepat waktu.

\section{Pengaruh Umur Perusahaan Terhadap Ketepatan Waktu Publikasi Laporan Keuangan}

Umur perusahaan memiliki nilai signifikansi sebesar 0,016 lebih kecil dari 0,05 berarti hipotesis 3 diterima dan variabel umur perusahaan berpengaruh signifikan terhadap ketepatan waktu pelaporan keuangan. Umur perusahaan merupakan hal yang dipertimbangkan calon investor dalam menanamkan modalnya, umur perusahaan akan dapat mencerminkan bahwa perusahaan tetap bertahan dan menjadi bukti bahwa 
perusahaan dapat bersaing di tengah persaingan bisnis. Semakin tua umur perusahaan maka cendrung lebih baik dalam pengelolaan kegiatan usaha perusahaan dan disamping itu juga perusahaan yang berusia lebih lama akan memiliki pengalaman dan kemampuan dalam menyiapkan publikasi laporan keuangannya secara tepat waktu.

\section{Pengaruh Kepemilikan Publik Terhadap Ketepatan Waktu Publikasi Laporan Keuangan}

Kepemilikan publik memiliki nilai signifikansi sebesar 0,961 lebih tinggi dari 0,05 yang berarti hipotesis 4 ditolak dan variabel kepemilikan publik tidak berpengaruh secara signifikan terhadap ketepatan waktu pelaporan keuangan. Hal ini disebabkan karena pada umumnya kepemilikan publik memiliki persentase kepemilikan yang relatif kecil dari semua pemegang saham yang dimiliki oleh perusahaan sehingga para pemegang saham publik tidak memiliki kekuatan dan pengaruh yang cukup untuk mengendalikan manajemen perusahaan dalam publikasi laporan keuangan yang tepat waktu.

\section{KESIMPULAN}

Berdasarkan hasil pengujian diperoleh hasil bahwa faktor keuangan yang terdiri dari likuiditas dan leverage tidak mempengaruhi ketepatan waktu publikasi laporan keuangan perusahaan. Hal ini ditunjukkan bahwa variabel likuiditas yang diproksikan dengan current ratio tidak berpengaruh terhadap ketepatan waktu publikasi laporan keuangan dan variabel leverage yang diproksikan Debt to Equity Ratio tidak berpengaruh terhadap ketepatan waktu publikasi laporan keuangan. Adapun faktor non keuangan yang diproksikan dengan variabel umur perusahaan berpengaruh terhadap ketepatan waktu publikasi laporan keuangan dan diproksikan dengan variabel kepemilikan publik tidak berpengaruh terhadap ketepatan waktu publikasi laporan keuangan.

\section{Implikasi Hasil Penelitian}

Hasil Penelitian ini diharapkan dapat memberikan informasi dan manfaat kepada pihak manajemen perusahaan, calon investor dan invenstor sebagai bahan pertimbangan pengambilan keputusan yang terkait dengan ketepatan waktu publikasi laporan keuangan. Dan peneliti selanjutnya sebagai referensi untuk digunakan dalam penelitian selanjutnya.

\section{Saran}

Saran bagi peneliti selanjutnya agar dapat mengembangkan penelitian yang lebih lebih luas lagi dengan menambah jumlah variabel penelitian, menambah jumlah sampel 
penelitian, meneliti perusahaan pada sektor lain, menambah tahun periode pengamatan yang lebih panjang dan dengan menggunakan alat analisis pengujian lainnya

\section{DAFTAR PUSTAKA}

Aprianti, Ine (2017). Analisis Ukuran Perusahaan, Profitability dan Debt To Equity Ratio Terhadap Ketepatan Waktu Pelaporan Keuangan. Vol 1 No. 2, hal $112-119$ pISSN : $2541-1691$.

Carolina, J. dan Tobing V. C. L. (2019). Pengaruh Profitabilitas, Likuiditas, Solvabilitas Dan Ukuran Perusahaan Terhadap Ketepatan Waktu Pelaporan Keuangan Pada Perusahaan Manufaktur di BEI. Jurnal Akuntansi Barelang, Vol. 3 No. 2, E- ISSN: $2580-5118$.

Diliasmara, D.A dan Nadirsyah. (2019). Pengaruh Profabilitas, Likuiditas, Financial Leverage, dan Strukur Kepemilikan Terhadap Ketepatan Waktu Pelaporan Keuangan pada Perusahaan Manufaktur Yang Tedaftar di Bursa Efek Indonesia Pada Tahun 2013 - 2015. Jurnal Ilmiah Mahasiswa Ekonomi Akuntansi (JIMEKA), Vol 4 No. 2, hal 304-316. E-ISSN : $2581-1002$

Fahmi, Irham. 2013. Analisis Laporan Keuangan. Bandung: Alfabeta.

Harahap, Sofyan Syafri. 2013. Analisis Kritis atas Laporan Keuangan. Cetakan ke-11. Jakarta: Rajawali Pers.

Hastutik, Suci. (2015). Pengaruh Profitabilitas, Likuiditas, Stuktur Kepemilikan, Ukuran Perusahaan Dan Opini Audit Terhadap Ketepatan Waktu Pelaporan Keuangan Perusahaan. Jurnal Akuntansi dan Sistem Teknologi Informasi, Vol. 11, hal 102 $-111$.

Hery. 2016. Mengenal dan Memahami Dasar - Dasar Laporan Keuangan. Jakarta: PT. Gramedia Widiasarana Indonesia

Imaniar, F. Q. dan Kurnia. (2016). Faktor - Faktor yang Mempengaruhi Ketepatan Waktu Pelaporan Keuangan Perusahaan. Judul IImu dan Riset Akuntansi, Vol. 5, No. 6, Juni 2016. ISSN : 2460-0585

Ikatan Akuntan Indonesia (IAI). 2018. Standar Akuntansi Keuangan revisi 2018. Jakarta : Salemba Empat.

Janrosl, Viola Syukrina E. (2018). Analisis Pengaruh Leverage, Ukuran Perusahaan Dan Profitabilitas, Terhadap Ketepatan Waktu Pelaporan Keuangan Pada Perusahaan Perbankan. Jurnal Benefita, 3 (2), ISSN : 196 - 203.

Kasmir. 2019. Analisis Laporan Keuangan. Cetakan ke-12. Jakarta: PT. Rajagrafindo Persada.

Lumbantoruan, A. F dan Siahaan S. B. (2018). Pengaruh Profitabilitas, Likuiditas, Ukuran Perusahaan, Umur Perusahaan, Keputasi KAP, dan Kepemilikan Manajerial Terhadap Ketepatan Waktu Pelaporan Keuangan Pada Perusahaan Otomotif dan Komponen Yang Terdaftar Di Bursa Efek Indonesia Periode 2012 - 2016. Jurnal IImiah Simantek, Vol. 2 No. 3, Juli 2018, ISSN : 2550 - 0414.

Munawir. 2014. Analisa Laporan Keuangan. Edisi Keempat. Yogyakarta: Liberty

Noor, Juliansyah. 2016. Metodologi Penelitian. Jakarta : Prenada Media 
Novelia, M. dan Rahayu, D. (2016). Pengaruh Return on Assets, Current Ratio dan Struktur Kepemilikan Terhadap Ketepatan Waktu Pelaporan Keuangan Pada Usaha Barang Konsumsi di Bursa Efek Indonesia. Dharma Ekonomi, No. 44/Th.XXIII/Oktober 2016, ISSN : 0853 - 5205.

Nurfauziah, Farah Latifah. (2016). Pengaruh Profitabilitas, Ukuran Perusahaan, Leverage, Dan Reputasi Kantor Akuntan Publik Terhadap Ketepatan Waktu Pelaporan Keuangan Audited. Jurnal Ekubis, Vol. 1 No. 1, Juli 2016, ISSN : 2541 $-1950$.

Nuro, R. J., Sochib dan Mudhofar, M. (2019). Pengaruh Profitabilitas, Kepemilikan Publik, Dan Opini Auditor Terhadap Ketepatan Waktu Pelaporan Keuangan Pada Perusahaan Yang Terdaftar di BEI Periode 2013 - 2015. Jurnal Riset Akuntansi, Vol. 1 No. 4

Peraturan Otoritas Jasa Keuangan (OJK) No. 44/POJK.04/2016 Tentang Laporan Lembaga Penyampaian dan Penyelesaiana

Peraturan Undang - Undang No. 8 Tahun 1995 Tentang Modal Saham

Prihadi, Toto. 2020. Analisis Laporan Keuangan. Cetakan ke-2. Jakarta: PT. Gramedia Pustaka Utama.

Sugiyono. 2017. Metode Penelitian Kuantitatif, Kualitatif dan R\&D. Cetakan ke-26. Bandung: Alfabeta.

Supriyono, R.A. 2018. Akuntansi Keprilakuan. Gajah Mada University Press

Putra, I G. A. P. dan Ramantha, I. W. (2015). Pengaruh Profitabilitas, Umur Perusahaan, Kepemilikian Institusional, Komisaris Independen, dan Komite Audit Pada Ketepatan Waktuan Publikasi Laporan Keuangan Tahunan. E-Jurnal Akuntansi Universitas Udayana, 10.1: 199-213. ISSN: $2302-8578$.

Prastyo, Ardian Dwi. (2016). Pengaruh Profitabilitas, Leverage, Likuiditas, Opini Akuntan Publik dan Rasio Aktivitas Terhadap Ketepatan Waktu Penyampaian Laporan Keuangan. Journal Riset Mahasiswa Akuntansi (JRMA), ISSN : 2337-56XX

Sanjaya dan Wirawati. (2016). Analisis Faktor-Faktor Yang Mempengaruhi Ketepatan Waktu Pelaporan Keuangan Pada Perusahaan Manufaktur Yang Terdaftar Di BEI. E-Jurnal Akuntansi Universitas Udayana. ISSN: 2302-8556.

Sembiring Yan Christin $\mathrm{Br}$. (2016). Pengaruh Rasio Leverage dan Kepemilikan Publik Terhadap Ketepatan Waktu Pelaporan Keuangan Pada Perusahaan Manufaktur yang Terdaftar di Bursa Efek Indonesia. JRAK. Vol. 2, No. 1, Maret 2016, ISSN : 2443: 1079.

Supartini, N. M., Endiana I. D. M., dan Kumalasari. P. D.(2021). Pengaruh Likuiditas, Ukuran Perusahaan, Umur Perusahaam dan Kepemilikan Publlik Terhadap Ketepatan Waktu Pelaporan Keuangan. Jurnal Kharisma. Vol. 3, No. 1, Februari 2021, E-ISSN : $2716-2710$.

Valentina I G A P Bunga dan Gayatri. (2018). Pengaruh Profitabilitas, Ukuran Perusahaan, Strukutur Kepemilikan, Leverage, Dan Umur Perusahaan Pada Ketepatan Waktu Pelaporan Keuangan. E-Jurnal Akuntansi Universitas Udayana, Vol.22.1 Januari (2018) : 572 - 594, ISSN : $2302-8556$. 